\title{
Erratum to: Visco-Resistive Dissipation in Strongly Driven Transient Reconnection
}

\author{
C.K. Armstrong • I.J.D. Craig
}

Published online: 30 October 2013

(C) Springer Science+Business Media Dordrecht 2013

\section{Erratum to: Solar Phys}

\section{DOI 10.1007/s11207-013-0363-z}

Due to a clerical error the Acknowledgements section was omitted from the article. It should have been:

Acknowledgements The authors would like to thank Yuri E. Litvinenko and the anonymous referee for their helpful comments.

The online version of the original article can be found under doi:10.1007/s11207-013-0363-z.

C.K. Armstrong ( $\varangle) \cdot$ I.J.D. Craig

Department of Mathematics, University of Waikato, Private Bag 3105, Hamilton, New Zealand

e-mail: cka3@waikato.ac.nz

I.J.D. Craig

e-mail: i.craig@waikato.ac.nz 